\title{
Recentralization of Local Government Chief Administrative Officers Appointments in Uganda: Implications for Downward Accountability
}

Commonwealth Journal of Local Governance

\author{
Lazarus Nabaho \\ Uganda Management Institute \\ Kampala, Uganda \\ Email:nabaho1@yahoo.com
}

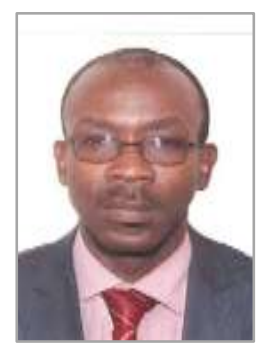

\begin{abstract}
The Uganda Constitution of 1995 spelt out the principle of decentralization by devolution. Accordingly, from 1995 to 2005, district local governments had a dejure mandate to hire and fire all categories of civil servants through their respective district service commissions (DSCs). Following the Constitutional amendment in September 2005, the right to hire and fire district chief administrative officers (CAOS) reverted to central government. Critics of recentralization of CAO appointments contend that the shift in the policy and legislation for managing CAOs runs contrary to the principles of decentralization by devolution. This paper argues that recentralization of CAOs has confused reporting, reduced the autonomy of sub-national governments in civil service management, undermined accountability of CAOs to elected councils, and shifted the loyalty of CAOs from local governments with and for which they work to central government that appoints and deploys them. To deepen accountability in local governments, the paper advocates for decentralization of CAO appointments, but for participation of central government in recruitment of CAOs within the confines of a separate personnel system. It further calls for a rethinking of the current call by the 9th Parliament to recentralize human resource in health in local governments owing to accountability challenges of managing the civil service in sub-national governments under an integrated personnel system.
\end{abstract}

Key words: Recentralization, Chief Administrative Officers, Accountability, Local Governments

\section{Introduction}

Uganda made a radical shift in decentralization policy and legislation in 2005. This shift entailed central government reclaiming powers to hire Chief Administrative Officers (CAOs) and deputy chief administrative officers. From 1995 to September 2005, local governments had a dejure mandate to appoint and discipline all civil servants, including CAOs through their respective district service commissions (DSCs). Placing CAOs under local councils was intended to deepen accountability of the $\mathrm{CAO}$ to elected representatives of the people. A locally accountable CAO was deemed to be a pillar of devolved local governance. 
Since recentralization of CAO appointments in 2005, the discourse on implications of recentralization for accountability in local governments has largely been at a conceptual level and has tended to echo arguments put forward before recentralization. As Manyak and Katono (2010: 8) asked,

Has recentralization [of $\mathrm{CAOS}$ ] seriously damaged the accountability link between elected and appointed officials at the district and local level?

This qualitative paper analyses the implication of recentralization of CAO appointments on downward accountability in local governments in Uganda. Data for the paper were gathered through interviewing three purposively selected CAOs and two elected district chairpersons from predominantly rural districts of Uganda, and were analyzed using thematic and content analysis. Though the findings are not generalizable to all local governments, they nuance our understanding of perverse effects of recentralization of appointment of local government staff on accountability in local governments. The paper extends scholarship on civil service management in local governments in Uganda from examining the underlying reasons for recentralization to considering the aftermath of recentralizing the appointment of the CAO.

\section{Background}

Uganda's current decentralization policy reform was launched in 1992 and consolidated through enactment of the of the Local Government (Resistance Councils) Statute in 1993 (Steiner, 2006; Muhumuza, 2008; Kakumba, 2008; Makara, 2009). The country's decentralization reform was labeled 'exceptional' among developing countries in terms of the scale and scope of the transfer of power and responsibilities to the local level (Steiner, 2006). Mitchinson (2003: 241) described Uganda's decentralization reform as: 'one of the most radical devolution initiatives in the developing world'..

Under Uganda's decentralization framework, the district is the highest level of local government. Below the district are lower local governments (municipalities, city divisions, town councils, and subcounties). The District Council is the highest political organ of local government and comprises the elected district chairperson as the political head plus a number of councilors representing electoral areas of the district and interest groups youth, people with disabilities and women) (Nabaho, 2012:79). Three fundamental innovations are discernible from Uganda's decentralization policy: a separate personnel system, intergovernmental fiscal relations, and a new power structure (Makara, 2009:137). Under the new personnel system, a District Service Committee was established in each district local government (under the Local Government (Resistance Councils) Statute, 1993 and Legal Notice Supplement 1 of 1994) and entrusted with the mandate to appoint, confirm, promote, and discipline all district and urban council employees, with exception of the district executive secretary (DES) and deputy district executive secretary (DDES). The DES was the head of the district public service as well as the accounting officer.

Following the promulgation of the 1995 Constitution, DESs and their deputies, who became CAOs and deputy CAOs under the new system, were also placed under the separate personnel system. This 
in effect meant that they would be appointed, disciplined and removed from office by the District Service Commissions (DSCs). Article 188 (1) of the Constitution (GoU 1995: 98) specifically stated that, 'There shall be a chief administrative officer for every district', while subsection (2) of the same Article stated that, 'The chief administrative officer shall be appointed by the district service commission and shall be the chief accounting officer for the district'.

The rationale for personnel decentralization was to make all staff executing decentralized functions accountable to local governments through the $\mathrm{CAO}$ or town clerk as the case may be (Nsibambi, 2000). The mandate of district local government to hire and fire their staff, including CAOs and their deputies, was further consolidated in the Local Government Act of 1997. The transfer of appointments to district local governments through the DSCs was considered to be one of the cornerstones of Ugandan decentralization reforms (Bossert \& Beauvais, 2002).

\section{Recentralization of appointment of Chief Administrative Officers}

In 2003, the Government of Uganda started rethinking the policy and local government legislation. One of the proposed policy shifts was recentralizing of CAO appointments, taking this responsibility away from DSCs. The related discourse from 2003 to September 2005 hinged on whether to recentralize CAOs or maintain the status quo. Competing views were expressed. Central government was the strongest pro-centralization voice, while the donor community and Uganda Local Government Association (ULGA) strongly opposed the imposition of an integrated personnel system on the district personnel arrangements. Japan International Cooperation Agency (JICA, 2008:21) has distilled the following as central arguments given in favour of recentralization of CAOs:

a) a central-government appointed $\mathrm{CAO}$ would be more protected from local political interference and pressures;

b) in view of the local government dependence on central government financial transfers, the CAO should be held centrally accountable to reduce rampant resource misappropriation;

c) recentralization would lead to recruitment of suitable CAOs; and

d) CAOs as senior civil servants would be transferable without being re-interviewed, which would reduce the turnover of CAOs and avoid equating decentralization with localization.

Let us contextualize the above issues. Admittedly, there was an urgent need to insulate CAOs from incessant and undue local political interference and pressures, but the point of contention was how to do it. Appointment of CAOs by districts - though good for downward accountability - exposed them to tremendous local pressure to contravene established regulations and procedures, especially on financial management and resource allocation (Kiyaga-Nsubuga \& Olum, 2009). CAOs who did not succumb to these pressures were dismissed by their respective DSCs (Francis \& James, 2003; KiyagaNsubuga \& Olum, 2009; Manyak \& Katono, 2010). Francis and James (2003) highlight a case where a DSC of one district dismissed a deputy $\mathrm{CAO}$, under pressure from the district executive, for 
questioning the use of the unconditional grant for elected leaders' allowances. Central government put forward three reasons for recentralizing CAO appointments.

First, recentralization was deemed a feasible strategy for shielding CAOs against political interference and to enhance their job security. Recentralization would enable the CAO to be independent from the political control of district councils. This would in turn create an environment for CAOs to operate within the provisions of the law as it would eliminate pressure on the CAO to approve illegal expenditure. Recentralization has evidently shielded CAOs against undue local political pressure. Mentor Consult (2008: 27) found that CAOs were satisfied with the decision to recentralize their appointment. One CAO is quoted in the Mentor Report as saying,

We are no longer puppets of what they [local politicians] would say; those days we would be forced to do things as they wanted because it was not possible to stand up to them.

This statement underscores the intense political pressure that CAOs were previously exposed to under the separate personnel system. However, there are justifiable fears in some quarters that recentralization may correspondingly shift political pressure on administrators away from local politicians to the central government.

Second, the rationale hinged on ensuring financial probity in the use of central government transfers under fiscal decentralization. The Local Government Act (CAP 243; GoU 1997) provides three types of fiscal transfers (conditional, unconditional and equalization grants) to local governments to implement their decentralized responsibilities (Muhumuza, 2008; Makara, 2009; Awortwi, 2011):

- Unconditional grants are given as a minimum grant to local government to run decentralized services.

- Conditional grants are given for services agreed with central government and provided by local governments, and may not be used for any other purpose apart from the one for which it is provided.

- Equalization grants are given to those local governments lagging behind the national average standards in service delivery (Makara, 2009).

By 1999, central government transfers amounted to over 93\% of the local government funding (Saito, 2003). At the same time, cases of resource misappropriation were frequently reported in the media, and reports of the Auditor General. In view of the above, central government argued for powers to appoint accounting officers who would be centrally accountable for central government transfers and use them frugally for maximum service delivery. Central government would therefore be in position to sanction accounting officers who flout financial management laws and regulations, in contrast to a separate personnel system where it would merely recommend to DSCs to take disciplinary action against errant accounting officers.

Third, it was argued that recentralization would pave the way for recruitment of suitable CAOs. Undoubtedly, the recruitment arrangements for local government staff, including CAO, tended and 
still tends to be inward looking and biased against candidates from other districts, favouring 'sons and daughters of the soil'- i.e. people of local origin (Francis \& James, 2003; Kakumba 2003, 2008; Awortwi, 2011; Nabaho, 2011, 2012; Nabaho \& Kiiza, 2013). Instead of appointing staff 'for the district from the national labour market', errant DSCs tend to appoint staff 'for the district from the local/district labour market' (Nabaho, 2012: 80), limiting opportunities for recruiting people with relevant competences (IGG, 2008). The decision by the Public Service Commission to retire some CAOs due to lack of requisite qualifications immediately after recentralization lends credence to the idea that some DSCs had breached merit principles during recruitment and selection of staff.

Fourth, under a separate personnel system CAOs and their deputies could not easily be transferred to another local government jurisdiction, but had to be re-interviewed and offered appointment on transfer of service. Critics argued that this approach to managing top local government administrators equated decentralization to localization, and that the separate personnel system confined them to a rather closed system where their career progress could easily be suffocated (Kakumba, 2008). Thus, any personnel arrangement that would enable CAOs to be transferred around the country would help their career development.

However, using recentralization of the $\mathrm{CAO}$ to achieve the objectives outlined above has been described by critics of recentralization as 'throwing the baby out with the bath-water'. Opponents of recentralization were unconvinced by these arguments and called for maintaining the status quo of the separate personnel management system for top local government staff. The Constitutional Review Commission Report, 2003 maintained the importance of having a locally accountable CAO as a pillar of devolved governance. The Commission argued that without local control of the CAO, councils would have limited control over the entire local government performance, and that central government appointment of CAOs would cut the most crucial accountability link between the elected local councils and local government staff, resulting in a snowball effect whereby local accountability would be undermined (Steffensen, 2006; JICA, 2008).

The Uganda Local Government Association (ULGA), in its submission to the Parliamentary Session Committee on Public Service and Local Government on Constitutional (Amendment) Bill No.2, 2005 and Local Governments (Amendment) Bill No.8, 2005 in May 2005, vehemently opposed recentralization of the CAO. ULGA (2005: 9) maintained that,

The proposal to revert to the position of LG[local government] CAOs being appointed and controlled at the CG [central Government] level is a recall of the already transferred powers possessed by LGs [local governments] in handling this particular office. It will confuse reporting and accountability. It will lead to more officers of LGs being recentralized. In the long run, the entire structure will collapse. CG already has its full representation through the Resident District Commissioner (RDC). The real outcome of the proposal in the Bill is the fact of recentralization against decentralization.

The anti-recentralization camp also argued that the proposed recentralization would undermine the principles and objectives of decentralization, by weakening the powers of the electorate, through their 
representative councils, to control technical staff. Recentralization would further raise issues of supervision and accountability of the CAO to districts.

However, those in favour of recentralization eventually won, and Parliament amended the Constitution in September 2005, and the Local Government Act 2006, to give responsibility for CAO appointments to the Public Service Commission (PSC). The status of the CAO has, since 2005, changed from one of being a district local government employee to that of being a central government employee in the district. Nevertheless, the CAO remains responsible to the elected district chairperson. Operationally, the PSC controls the appointment and exercises disciplinary control over the $\mathrm{CAO}$; routine management (posting and transfer) of the CAO is a responsibility of the Ministry of Local Government, while the CAO's performance appraisal is handled by the elected district chairperson. Recentralization of the CAO has definitely changed the texture of human resource management in local governments.

During the decade from 1995 to 2005 the entire human resource management function in local governments operated under a completely separate personnel arrangement. Uganda has now gone back to the pre-1995 arrangement for managing CAOs - a move labeled by some as 'the President [Yoweri Museveni] killing his own baby [decentralization by devolution]' (Manyak \& Katono, 2010: 5). It is now evident that Uganda's local government system has a dual character: an integrated personnel system for CAOs, deputy CAOs and municipal town clerks, and a separate personnel system for other local government staff (Kakumba, 2008; Nabaho, 2011, 2012; Nabaho \& Kiiza, 2013). This apparent policy shift has changed the philosophical basis of decentralization by devolution and created tensions between the philosophy and practice of decentralization (KiyagaNsubuga \& Olum, 2009).

\section{Post-recentralization discourse on recentralizing CAO appointments}

The critical question for scholars of local governance is why the provisions of the repealed Local Government (Resistance Councils) Statute, 1993, concerning management of top local government administrators were resurrected in September 2005 through amendment of the 1995 Constitution and Local Government Act (CAP 243). In other words, why did the arrangement for managing top administrators revert to a system that operated a decade earlier and that was at odds with the principles of decentralization by devolution?

The decision to recentralize $\mathrm{CAO}$ appointments can be explained by two principal factors: the declining political fortunes of the National Resistance Movement (NRM) government and central government's uneasiness at the extent of autonomy granted to local governments under the 1995 Constitution and the Local Government Act (CAP 243). Thus scholars challenge the reasons advanced by the NRM government for recentralization of CAO appointments, variously described 'ostensible' and 'supposed', arguing that the NRM government used corruption as a scapegoat to achieve its political objectives (Muhumuza, 2008). Skeptics of this anti-corruption strategy argue that 
corruption cannot be tacked by centralizing the office of the CAO, and that corruption at the local government level should be tackled by strengthening the local mechanisms of accountability and improving national oversight agencies such as the Office of the Auditor General and the Inspectorate of Government (Oloka-Onyango, 2007). Improving local accountability resonates well with the principal-agent frameworks which hold that corruption is a function of monopoly plus discretion less accountability (Klitgaard, 1988). CLGF (2007) casts doubt over the potential of recentralization to curb corruption by arguing that the CAO with central allegiance would be operating in the same corrupt environment.

Scholars further attribute recentralization of CAO appointments to electoral politics at the national level. From 1986 to 2005, the NRM established a defacto one-party system which; its proponents called 'no party' or 'movement', but which critical observers aptly noted simply meant that no other political party had a role in the governance of the country (Makara, 2009). This period also witnessed CAOs performing an additional role of retuning officer on behalf of the Electoral Commission during national and local council elections. Quite often, the NRM establishment accused CAOs of being 'multipartists' prior to the ushering in of 'multipartism' in 2005. In the past, where the NRM lost in elections, President Museveni accused CAOs of conniving with the opposition (Awortwi, 2011:368). Oloka-Onyango (2007:37) draws a strong link between 2006 presidential and parliamentary elections and recentralization of the appointment of the CAO:

Why the CAO was recentralized was clearly also related to fears around the elections with several powerful NRM officials accusing CAOs of being 'multipartists' and therefore lacking the necessary partiality in their role as designated election returning officers.

This position was reconfirmed when, after the February 2006 elections, President Museveni accused CAOs of being sympathizers of opposition political parties and threatened to appoint only those who subscribe to NRM government philosophy as CAOs (Awortwi, 2011). Immediately after 2006 elections, all CAOs were required to apply for their jobs alongside new applicants. Recentralization of CAOs was therefore part of a broader scheme by government to minimize the risk of losing to any competitor (Awortwi, 2011).

Steffensen (2006), however, sees the NRM government's recentralization of CAO appointments as a symptom of unease with the level of autonomy of local governments, and the wish by central government to strengthen control. Following several amendments to local government legislation, commentators argued that the NRM [ruling party] had become fearful of its own 'success' in pursuing decentralization (JICA, 2008). Local government autonomy was manifested in three powers: power to make and enforce regulatory decisions; power to govern a procurement system; and power to manage human resources. Recentralization of some elements of local government personnel management, including the appointment of CAOs and municipal town clerks, was considered an effective way of weakening the autonomy of local governments. In parallel, in 2006 the Local Government Act was amended to strip local governments of the power to govern a procurement system, abolishing the former local tender boards that were appointed by councils. However, there were accusations that 
these procurement entities had become instruments of cronyism and patronage and were corrupt (CLGF, 2007). Tender boards were replaced with contract committees appointed by the CAO and eventually approved by the Secretary to the Treasury ${ }^{14}$. Currently, local governments have no role in contract committees and their power to query decisions of the committees is limited. The NRM government is also using intergovernmental fiscal transfer arrangements to reduce the autonomy of local governments (JICA, 2008), and central government fiscal transfers have been placed under central government appointees (CAOs) which undermines decentralization reform (ARD, 2005). All these changes support to the assertion by Awortwi (2011:348) that while central government leadership finds it expedient to appear to support a decentralization policy, they do not wish to see the growth of powerful local institutions.

One major conclusion from the analysis above is that central government-driven human resource management reforms for local governments do not take place in a vacuum; they are shaped by the political environment at the national level and the desire by the central government to exercise tight control over sub-national governments.

\section{Has recentralization of CAO appointments undermined accountability?}

Accountability, as a concept, has been in the public domain for many years. The concept lends itself to many interpretations. Brinkerhoff (2001:2) opines that the essence of accountability is answerability; being accountable means having the obligation to answer questions regarding decisions and/or actions. Accountability has two important dimensions: answerability and enforcement. Answerability refers to the obligation to provide information and explanations concerning decisions and actions while enforcement is the ability to oversee actors and apply sanctions when they give unsatisfactory answers (Brinkerhoff, 2001:2-5). Recentralization of the CAO has apparently impacted on accountability in local governments in two major ways: shift in reporting and allegiance of top administrators in districts; and weakening control over the CAO by elected councils.

\section{Shift in reporting and allegiance}

No servant can serve two masters; for either he will hate the one and love the other, or else he will be loyal to the one and despise the other ... (Luke 16:13,NKJV).

Recentralization has created two masters for the CAO: the district council and central government. This has shifted the pattern of reporting for the CAO from being uni-directional to being bidirectional. Currently, the CAO reports upward to central government and downward to the district council. Asked about implications of recentralization on reporting arrangements for top administrators in local governments, one respondent said, 'Recentralization [of CAO appointments] has created two reporting centres', which has attendant implications for accountability of the highest civil servant in

14 The permanent secretary in charge of finance, planning and economic development 
district local governments. As one key informant put it, 'The CAO looks to the central government as the priority reporting centre'.

There was a general consensus among the two elected district chairpersons interviewed that CAOs were mostly preoccupied with accountability to central government, which has in turn softened accountability in local governments. This finding did not come as a surprise since central government wields substantial power over the $\mathrm{CAO}$ by virtue of being the appointing, posting and sanctioning authority. Practically, the recruiter of the CAO (central government) and a mere recipient of the CAO (local government) cannot have the same standing.

Similarly, there was a general perception among elected district chairpersons and CAOs interviewed for this research that two-way reporting had considerably affected the loyalty of the CAOs, who now suffer from 'operational' loyalty to local councils and their 'career' loyalty to central masters. An acting CAO who had served in three local governments after recentralization spoke of how challenging it was for the $\mathrm{CAO}$ to please both powers. One CAO described the current dilemma of CAOs as 'being caught between a rock and a hard place'. The hardest choice a CAO has to make is whether his/her loyalty should lean more to the 'local governments with and for which he/she works' or to the central government that appoints and deploys him/her to districts. Another CAO likened the current predicament of CAOs to "a woman married to two husbands".

Elected district chairpersons were of the view that CAOs had strategically shifted their allegiance to central government. They revealed that some CAOs now conveniently ignore a local council directive if this is not in the interest of central government. However, CAOs cannot completely ignore loyalty to local governments, since they are assigned to help local governments fulfill their statutory powers. This dichotomy reinforces the argument that an integrated personnel system occasions split loyalties for senior officials managing decentralized services (Nabaho, 2012). Thus an integrated personnel system appears to be the antithesis of decentralization by devolution. One conclusion that stems from the above discussion is that in a decentralized context, civil servants tend to owe allegiance to a local government they are appointed to serve rather than one in which they are assigned to work by central government.

At a policy level, the findings of this qualitative study on unintended consequences of human resource recentralization for employee loyalty should inform the current debate in Uganda on whether to recentralize the appointments of health sector staff employed through local governments. The Parliamentary Committee on Health (Parliament of Uganda: 2012: 25) has already recommended to Parliament that,

... recruitment and supervision of health workers in lower health centres [district hospitals and health centres 2 to 4] should be recentralized to make it possible for the Health Service Commission to recruit them instead of the District Service Commissions, which in most cases lack the capacity. 
The committee intends to move a Private Member's Bill to that effect. The findings in this paper, suggest that accountability and loyalty concerns should be integral to debates on whether to recentralize human resource management for health staff or to maintain the status quo. The debate should also be underpinned by scholarly analysis of other local governance systems in Africa that attest to perverse effects of central government appointment and posting of civil servants to local governments. With reference to Ghana, Awortwi (2011: 367-368) writes,

Civil servants have no allegiance to the LG [local government] in whose jurisdiction they work and they frequently ignore $L G$ policies and priorities, refuse to attend meetings with locally elected officials, and generally maintain allegiance to the CG [central government]. Locally elected councilors face severe frustrations in the very assembly they are supposed to control.

It is therefore advisable that central government should conduct a thorough evaluation of recentralization of CAO appointments on service delivery in local government before recentralizing more local government staff. From the perspective of political heads of districts (the two elected district officers interviewed), there is anecdotal evidence that recentralization has not achieved much, save ensuring job security for CAOs and giving the function a national outlook. As one said, 'Recentralization has caused more harm than good to local government service delivery'.

According to elected district officers, its effects have been threefold. First, CAOs are out of their duty stations (districts) most of the time since they have to balance performing their official duties and attending to their 'non-resident' families - some CAOs were described as 'visitors to districts' and their absence as 'a norm rather than an exception'. Quite often, CAOs do not seek permission from elected district chairpersons (to whom they are responsible) to be away from work and from districts, and chairperson, a former senior civil servant, said that he recently had to issue a warning letter to a CAO over rampant absenteeism from the district without permission. The elected district chairpersons argued that perennial absence of CAOs affects district operations and partly explains why districts return billions of unspent central government transfers to the national treasury at the end of the financial year. Re-remittance of central government transfers to the national treasury is not confined to the districts in this study, and Kaberamaido district reportedly returned 400 million Uganda shillings (150,944 United States dollars) to the national treasury at the end of 2011/2012 (Onyinge, 2013).

Second, after being transferred, most CAOs regularly delay to report to their new duty stations which has a considerable toll on local government service delivery. Thirdly, when CAOs are transferred, they take considerable time to acclimatize to districts. The 'acclimatization phase' has ramifications on the performance of sub-national governments. This is exacerbated by the short interval at which CAOs are transferred from one district to another either at the volition of the Ministry of Local Government or at the request of district local government councils. 


\section{Limited control by elected officials over CAO}

Recentralization has, without doubt, substantially reduced the control of elected politicians over top administrators in local governments. CAOs thought that elected district chairpersons were concerned that recentralization deprived them of their powers, and elected leaders affirmed this. Though the $\mathrm{CAO}$ is responsible to the elected district chairperson and the district council, the chairperson and council cannot sanction the $\mathrm{CAO}$, in contrast to the pre-recentralization era, where district councils could remove CAOs through DSCs. Under the current legal regime, councils can only recommend removal of a $\mathrm{CAO}$ by a resolution supported by two-thirds of the council members on four grounds: abuse of office, incompetence, misconduct or misbehavior; or physical or mental incapacity.

Elected district chairpersons were of the view that CAOs now feel they are superior and exhibit arrogant tendencies toward councilors and elected district chairpersons, for example absence without leave was described by elected chairperson as "CAOs undermining their supervisors". Thus, centralization has also rendered councils powerless in dealing with the CAO. The behavior of some CAOs towards elected leaders in local governments is a clear manifestation of how laws and policies can influence the behavior of actors in formal organizations.

\section{Conclusion}

It is evident that since 2005, there have been calculated and steady attempts by central government to unravel components of Uganda's decentralization. This paper has demonstrated how recentralization of CAO appointments has negatively impacted on reporting and accountability in local governments at a time when there are renewed calls to strengthen accountability as a key pillar of good governance, and there are no proposals for strengthening accountability of CAOs (and the entire local government civil service). The remedy for strengthening accountability of civil servants to council is to revert the responsibility of appointing CAOs to local governments to ensure that there is no disconnect between the principle of decentralization by devolution and the practice of human resource management in sub-national governments. Nevertheless, central government should, within the confines of a separate personnel system, play a visible role in recruitment of the CAO. Within the proposed devolved arrangement, it should be made mandatory for the Public Service Commission, the Ministry of Public Service, and Ministry of Local Government to be involved in recruiting the CAO. The same central government institutions should be given powers to veto any major disciplinary action administered against the CAO by local governments to avoid victimization and unfair disciplinary action. Similarly, accountability institutions at national and local level should be strengthened to deal with cases of financial mismanagement in local governments. These proposed measures will ensure recruitment of suitable CAOs (since recruitment is likely to transcend ethnic and boundary considerations), guard against unfair disciplinary action(s) against CAOs, and lessen the motivation of CAOs to breach financial laws and policies. 


\section{References}

ARD, Inc. (2005) Democracy and Governance Assessment: Republic of Uganda. Report prepared for United States Agency for International Development (USAID). Burlington, VTwortwi, N. (2011). An unbreakable path? A comparative study of decentralization and local government development trajectories in Ghana and Uganda. International Review of Administrative Sciences, 77(2), 347-377

Awortwi, N. (2011) An unbreakable path? A comparativestudy of decentralization and local government development trajectores in Ghana and Uganda, International Review of Administrative Sciences, 77(2); 347-377

Bossert, T.J. \& Beauvais J. (2002) Decentralization of Health Systems in Ghana, Zambia, Uganda and the Philippines: A Comparative Analysis of Decision Space ${ }^{e e}$, Health Policy and Planning 17(1), 14-31

Brinkerhoff, D.W. (2001) Taking Account of Accountability: A Conceptual Overview and Strategic Options. Draft report for the Implementing Policy Change Project, Phase 2, Center for Democracy and Governance, USAID. Abt. Associates, Inc., Washington, DC. Mimeo

CLGF (2007) Meeting the Challenges of the Aberdeen Agenda: An Assessment of Local Governance and Democracy in Uganda, report commissioned by CLGF. London: (CLGF) Commonwealth Local Government Forum

Francis, P \& James, R. (2003). Balancing Rural Poverty Reduction and Citizen Participation: The Contradictions of Uganda's Decentralization Program. World Development, 31(2), 325-37

GoU. (1995) Constitution of the Republic of Uganda, 1995. GoU (Government of Uganda) Kampala: Uganda Printing and Publishing Corporation

GoU. (1997) Local Government Act (Cap 243). GoU (Government of Uganda) Kampala: Uganda Printing and Publishing Corporation

IGG. (2008) Final Report of the Third National Integrity Survey, Kampala: IGG (Inspectorate of Government)

JICA (2008) .Decentralized Service Delivery in East Africa, A Comparative Study of Uganda, Tanzania and Kenya. Uganda Country Report, Research Group, Institute for International Cooperation, JICA (Japan International Cooperation Agency). Tokyo

Kakumba , U. (2008) External control systems of accountability in Local Governments: the case of Uganda. Unpublished $\mathrm{PhD}$ thesis, University of Pretoria, South Africa

Kakumba, U.( 2003) The Challenges of Personnel Decentralization and Local Government Performance in Uganda: The Case of Luwero District. Unpublished Masters dissertation, Makerere University, Kampala, Uganda

Kiyaga-Nsubuga, J \& Olum, Y. (2009) Local Governance and Local Democracy in Uganda, Commonwealth Journal of Local Governance, 2, 26-43

Klitgaard, R. E. (1988) Controlling Corruption. Berkeley: University of California Press

Makara, S. (2009) Decentralization and urban governance in Uganda. Unpublished PhD thesis, University of Witwatersrand, South Africa

Manyak, T.G, \& Katono, I. (2010) Decentralization and Conflict in Uganda, African Studies Quarterly, 11(4), 124

Mentor Consult. (2008) Draft Report on Africa Local Council Oversight and Social Accountability (ALCOSA) Studying Local Council Oversight in Uganda. Available at http://siteresources.worldbank.org/.../Resources/.../uganda_stageII_s.pdf

Mitchinson, R. (2003) Devolution in Uganda: An experiment in local service delivery. Public Administration and Development, 23(3), 241-248

Muhumuza, W. (2008). Pitfalls of Decentralization Reforms in Transitional Societies: The Case of Uganda. Africa Development, 33(4), 59-81

Nabaho, L \& Kiiza, A. (2013) Human Resource Management in Local Governments: An analysis of Recruitment and Selection Practices in Uganda. Journal of African and Asian Local Government Studies, 2(2), $1-14$. 
Nabaho, L. (2012) Driving up Standards: Civil Service Management and Decentralization: Case Study of Uganda, Commonwealth Journal of Local Governance, 11, 75-94

Nabaho, L. (2011) Managing the Civil Service in Local Governments under the Separate Personnel System: Challenges and Policy Issues. Paper presented at the $33^{\text {rd }}$ African Association for Public Administration and Management (AAPAM) Annual Roundtable Conference held in Lilongwe, Malawi, from 14-18 November 2011

Nsibambi, A (ed). (2000) Decentralization in Uganda: the quest for good governance. Kampala: Fountain Publishers

Oloka-Onyango, J. (2007) Decentralization without human rights: Local governance and access to justice in post-Movement Uganda. Kampala: Human Rights and Peace Centre

Onyinge, M. (2013, March 27) LC 3 Chairpersons Lock Kaberamaido District Offices. The New Vision, pp, 8.

Parliament of Uganda. (2012) Report of the Parliamentary Committee on Health on the Ministerial Policy Statement for the Health Sector for the Financial Year 2012/2012. Available at www.parliament.go.ug/.../45committee-on-health?...health...minister.. (Accessed on 17/03/2013)

Saito, F. (2003) Decentralization and Development Partnerships_.Tokyo: Springer.

Steffensen, J. (2006) Local Government Organization and Finance: Uganda, in Anwar, S. (ed.), Local Governance in Developing Countries, Washington, DC: World Bank, pp. 93-136

Steiner, S. (2006) Decentralization in Uganda: Exploring the Constraints for Poverty Reduction.GIGA Working Paper No. 31

ULGA (2005). Submission on the Constitution (amendment) (No. 2) Bill 2005, other provisions pertinent to local governments and local governments (amendment) Bill No. 8, 2005 to the parliamentary session committee on public service and local government, May, (UGLA) Uganda Local Government Association: Kampala 